\title{
The Impact of Green Supply Chain Management Practices on Organizational Performance: A Study of Jordanian Food Industries
}

\author{
Salah M. Diab ${ }^{1}$, Faisal A. AL-Bourini ${ }^{1} \&$ Asad H. Abu-Rumman ${ }^{2}$ \\ ${ }^{1}$ Business Administration Department, Economics and Administration Faculty, Applied Science University, \\ Amman, Jordan \\ ${ }^{2}$ Marketing Departments, Economics and Administration Faculty, Applied Science University, Amman, Jordan \\ Correspondence: Salah M. Diab, Business Administration Department, Economics and Administration Faculty, \\ P. O. BOX 166, Applied Science University, Amman 11931, Jordan. E-mail: salahdiab2002@yahoo.com
}

Received: November 28, 2014 Accepted: January 19, 2015 Online Published: February 20, 2015

doi:10.5539/jms.v5n1p149 URL: http://dx.doi.org/10.5539/jms.v5n1p149

\begin{abstract}
The purpose of this study is to test The Impact of Green Supply Chain Management Practices on Organizational Performance: A study On Jordanian Nutrition Industries. The Data was collected through a questionnaire; the consistency percentage was $85 \%$; Cranach's alpha for all the domains and the whole tool is (0.89). Means, standard deviation, and simple and multiple linear regressions analysis were used to test the study hypothesis and the relationships between the dependent and independent variabeles. The researcher built the model and hypothesis based on the dimensions of green supply chain management practices. The researchers chose (6) firms specialized in industrial food sector and which the firms that applied the concept of green manufacturing. The results of the study showed that there was an impact of green supply chain management practices and its elements on organizational performance. The implications of this study are; academic implications, and managerial implications. The researchers include all the green supply chain management elements, on organizational performance which are; environmental performance, financial performance, and Operational Performanc. As a recomendation for this study, it may play an important role for managers and firms through understanding the green supply chain management and increasing the sales and benefits.
\end{abstract}

Keywords: the green supply chain, Jordanian food industries, organizational performance

\section{Introduction}

Balancing between economic and environmental performance has become increasingly important for organizations facing competitive, regulatory, and community pressures (Shultz \& Holbrook, 1999). With increased pressures for environmental sustainability, it is expected that enterprises will need to implement strategies to reduce the environmental impacts of their products and services (Zhu \& Sarkis, 2001, p. 123). To establish their environmental image, enterprises have to re-examine the purpose of their business. Success in addressing environmental items may provide new opportunities for competition, and new ways to add value to core business programs (Carter \& Carter, 1998, p. 87). Approaches, such as cleaner production, environmental management systems and eco-efficiency, have been implemented for green management practices. Green supply chain management (GSCM) has a key role in ensuring that all of these factors are addressed (Carter \& Ellram, 1998, p. 113). Environmental impacts occur at all stages of a product's life cycle. Therefore, GSCM has emerged as an important new archetype for enterprises to achieve profit and market share objectives by lowering their environmental risks, and the impacts, while raising their ecological efficiency (Gupta, 1995, p. 200). In this study we try to know if theres an impact of green supply chain management practices (internal environmental management, collaboration with customers, green purchasing, eco-design and packaging, warehousing and green building) on company performance (environmental performance, financial performance, and operational performance) a study on Jordanian nutrition industries (Carter \& Grimn, 2000, p. 223). Also Jordanian Government has big concern for applying the green economy through applying some regulatory decision as green investment law, renewable energy law and also other laws that deal with green economy. 


\section{Theoretical Framework}

\subsection{Green Supply Chain Management Practices}

We have compelling and ever more urgent duty of stewardship, to take care of the natural environment and resources on which our economic activity and social fabric depend. Firms are facing growing pressure to become reasonable and greener, several stockholders press companies to reduce their negative impacts on society and natural environment (Josef \& Maria, 2009).

The concept green supply chain practices (GSCP) is commonly used for a variety of activities performed by an organization in order to minimize their impacts on a natural environment supply chains strive to maintain internal health and environmental sustainability using the capability to self correct based on information from the external environment (Vochon \& klessen, 2007).

The balancing between economic, environmental, operational, and financial performance has become increasingly important for organizations facing competitive regularly and community pressures (Shultz \& Holbrook, 1999).

GSCP definition has ranged from green purchasing to integrated supply chains flowing from suppliers to manufacturer, to customers and reverse to logistics, which is "closing the loop" as defined by supply chain practices. Whatever the definition of GSCP is considered a potential impact of GSCP on a firm's performance (Zhu \& Sarkis, 2004) mentioned that a potential three-fold effect on the performance of the companies: impact on environmental performance (i.e., reductions of air, wastewater, solid waste, and decrease of frequency for environmental accidents.); impact on financial performance (i.e., decrease of cost for material purchasing, energy consumption, and waste treatments); impact on operational performance (i.e., increased amount of goods delivered on time, scrap rate, and product line, on the other hand decrease inventory levels, promote products quality, and improved capability utilization). The system components of the supply chain as (Chandra \& Tunmanyan, 2005) drown: Whereas Inputs, physical item, information, or services that necessary to start a process, through reduced volumes of row materials. Outputs, physical item, information, or services that results from processing an input, which related to the total, through management of reverse logistics and green out bound logistics. The Process, flows, transformations, or order of steps, which transform the input into output, are through internal environmental operations management practices of eco-efficiency. Environment relates to resource requirement, both physical and human, through drivers that influence the adoption of green practices from within the organization and the external environment. Agent, computational, or human resources for carrying the process, is through specific job roles to promote environmental behavior including supplier's management. Mechanism, physical or local facilities in the generation of an output, is through mapping of waste by products, or supplier assessment questionnaire or accreditation to an environmental management standard. Function, mission, aim or primary concern of the system, through over all function is to provide the desired output which has a lower environmental burden.

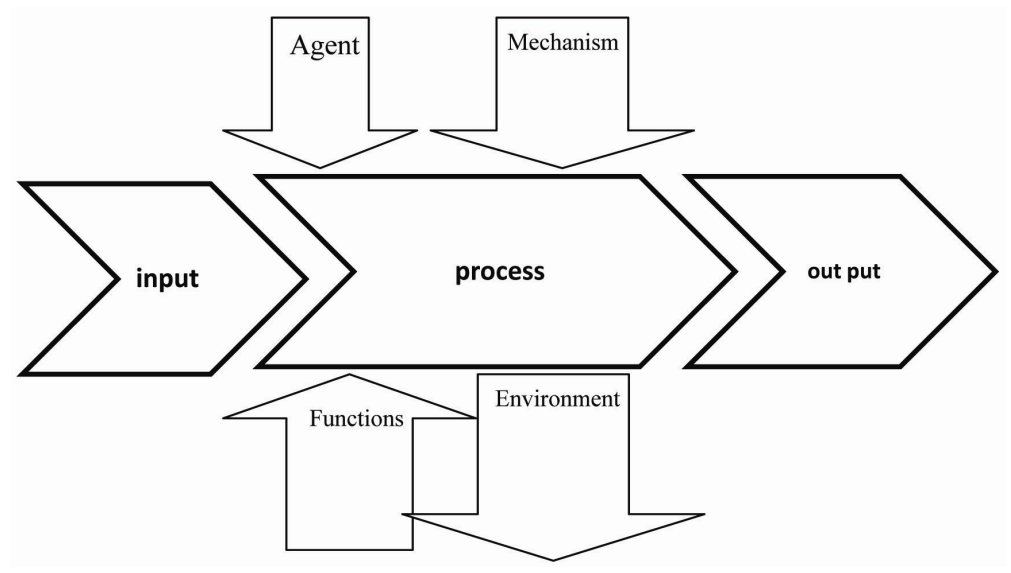

\subsection{Internal Environmental Management}

Internal Environmental Management is the practice of developing environmental sustainability as strategic organizational imperative through commitment and support of the imperative from senior and mid-level managers (Zhu \& Sarkis, 2007). 


\subsection{Collaboration with Customers}

Collaboration with customers is working jointly with customers to set and achieve environmental goals that result in the reduction of the environmental impact of coordinated activities, in addition to compliance with customers' requirements related to the implementation of environmental management systems, compliance with customers' environmental requirements, and informing customers of compliance their environmental requirements (Theyel, 2001, p. 88). Cooperation with customers requires working with customers to design cleaner production processes that Produce environmentally sustainable products with green packaging (Sarkis, 2003, p. 98).

\subsection{Green Purchasing}

Green purchasing involves an organization assessing the environmental performance of their suppliers, which requiresthe suppliers to undertake measures that ensure environmentalquality in their operational systems. Green purchasing is defined as "environmental plans for a firm's long-term material, component or system requirements" suggesting that the purchasing function may help to evaluate the amount of waste flowing into business systems (Zhu \& Sarkis, 2007, p. 321).

\subsection{Eco-design and Packaging}

Eco-design requires that manufacturers design products that minimize consumption of materials and energy, that facilitate the reuse, recycle, and recovery of component materials and parts, and that avoid or reduce the use of hazardous products within the manufacturing (Sarkis, 2003, p. 134).

\subsection{Warehousing and green building}

The location analysis must insure that the warehousing and buildings have a safety through storage, transportation, packaging, distribution; forward logistics in addition to investment recovery requires the sale of excess inventories, scrap and used materials, and excess capital equipment. The Investment recovered (sale) of excess inventories/materials and, Sale of scrap, used materials, and Sale of excess capital equipment (Hall, 2001, p. 161).

\subsection{Organizational Performance}

Consist from the Environmental Performance, Financial Performance, and Operational Performance.

\subsection{Environmental Performance}

Environmental Performance includes and concentrates on reduction of air emission, reduction of waste water,reduction of solid wastes ,in addition to decrease of consumption for hazardous/harmful/toxic materials, decrease of frequency for environmental accidents , andImprove an enterprise's environmental situation (Alvarez, 2001, p. 88)

\subsection{Financial Performance}

Financial Performance, includes and concentrates on Positive economic performance, were are decrease of cost for materials purchasing, decrease of cost for energy consumption, decrease of fee for waste treatment, decrease of fee for waste discharge, and at the same time trying to eliminate the negative economic performance, such as, increase of investment, increase of operational cost, increase of training cost, increase cost of purchasing environmentally friendly materials (Melnyk, 2002, p. 375).

\subsection{Operational Performance}

Operational performance; any organization needs to be success in it operational. This success reflected on the Increase amount of goods delivered on time, decrease inventory levels, decrease scrap rate, promote products' quality, increased product line, and improved capacity utilization (Min \& Gale, 1997, p. 138).

\section{Previous Studies}

A study by (Perotti, 2012), the study found that the current level of adaptation of GSCP is still limited amongst the economic, environment, and operational, investigated as well as their benefits in terms of company performance, and Some players have shown a more proactive attitude and started benefiting substantially from adoption of GSCP, mainly in terms of environmental and economic performance. But Holt and Ghobadain (2009) the study found that the average manufactures perceived the greater pressure to improve environmental performance through legislation and internal drivers. Bjorklund et al. (2012) the study found that the design of environmental performance measurements in supply chain management and identifies shortcomings in existing research. The case presents successful examples of how environmental performance measurements can be applied across managerial levels as well as company borders in a supply chain. But Kenneth, Green, Zelbst, and 
Bhadauria (2012) the study found that the adoption of GSCM practices by manufacturing organizations leads to improved environmental performance and economic performance, which, in turn, positively impact operational performance. Operational performance enhances organizational performance. Victor Guang Shi, Lenny Koh, James Baldwin and Federica Cucchiella (2012) the study found that the constructs are identified in terms of intra- and inter-organizational environmental practices, performance measures and institutional drivers, the Causal relationships, within and between the constructs.

\section{Study Problem}

The Jordanian Government has big concern for applying the green economy through applying some regulatory decision as green investment law, renewable energy law and also other laws that deal with green economy. The problem of the study summarized in a range of questions, which are:

-What is the impact of green supply chain management practices: internal environmental management, collaboration with customers, green purchasing, eco-design and packaging, and warehousing and green on organizational environment performance?

-What is the impact of green supply chain management practices: internal environmental management, collaboration with customers, green purchasing, eco-design and packaging, and warehousing and green on organizational financial performance?

-What is the impact of green supply chain management practices: internal environmental management, collaboration with customers, green purchasing, eco-design and packaging, and warehousing and green on organizational operational performance?

\section{Study objectives}

The objectives of this study are summarized as follows: test and measure the impact of green supply chain management practices: internal environmental management, collaboration with customers, green purchasing, eco-design and packaging, and warehousing and green on organizational performances: environment performance, financial performance, and operational performance, in addition to provide a simple theoretical framework for the study variables,make appropriate recommendations in the light of the results of this study, which may lead to improved performances, and addressing a topic that hasn't been studied before, at the Jordanian food industries.

\section{Framework and Research Hypothesis:}

\subsection{Research Framework}

The proposed framework for this research is illustrated in Figure 1. The framework shows the impact of Green supply chainmanagement practices on the Organizational Performance.

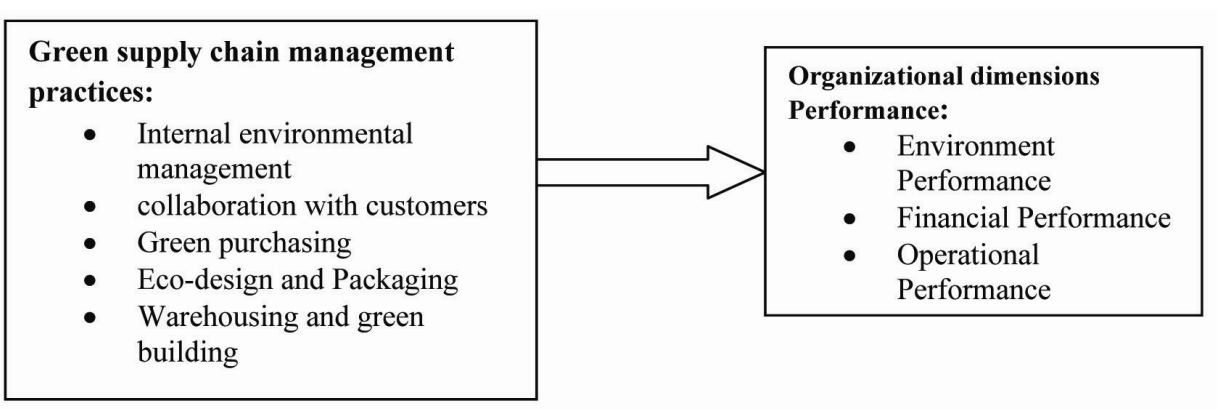

Figure 1. Research framework (study model)

\subsection{Research Hypothesis}

6.2.1: Ho: there is no significant impact of green supply chain management practices(combined);(internal environmental management, collaboration with customers, green purchasing, eco-design and packaging, and warehousing and green) on organizational performance(combined)( environment performance, financial performance, and operational performance). 
6.2.2: Ho: there is no significant impact of green supply chain management practices (combined) (internal environmental management, collaboration with customers, green purchasing, eco-design and packaging, and warehousing and green) on organizational environment performance.

6.2.3: Ho: there is no significant impactof green supply chain management practices (combined) (internal environmental management, collaboration with customers, green purchasing, eco-design and packaging, and warehousing and green) on organizational financial performance.

6.2.4: Ho: there is no significant impact of green supply chain management practices (combined) (internal environmental management, collaboration with customers, green purchasing, eco-design and packaging, and warehousing and green) organizational operational performance.

\section{Methodology}

\subsection{Population and Data Collection}

The researchers choose (6) firms specialized in industrial food sector and it was chosen based on the size and profitability. The sample represented by the firms which specific in food industry in Jordan, and the sample has been chosen from (6) firms, which firms that apply green manufacturing concepts and which got the ISO 14001 related to environment.

\subsection{Data Collection Method}

Primary Data: the researcher used the questionnaires as a primary data, while secondary data has been used as literature, books, articles, case studies, and websitein order to help preparing the theoretical framework and the whole study.

\subsection{Validity and Reliability}

Validity for the questionnaire was evaluated from four members of Applied Science University. Study reliability were calculated by using test pre-test, in which the researcher applies the study tool on a sample of 50 customers of the sample, after three weeks the sample was tested again, the consistency percentage was $85 \%$; and to make sure of the results the researcher computed Cranach's alpha for all the domains and the whole tool, the value (0.89). The following table 1 showed the Cronbach alpha for each dimensions of green supply chainmanagement practices, and also the dimensions of organizational performance, and also the table showed the factors loadings value for each dimensions of the study. While the factor loadings' value ranging between moderate and high, which indicated that the questions were effectively fit for the dimensions and variables of the study.

Table 1. Results of measure validation

\begin{tabular}{lll}
\hline Items & Factor loadings & Cronbach alpha \\
\hline Internal Environmental Management & $0.568-0.900$ & 0.658 \\
(IEM) & & \\
Collaboration with Customers (CWC) & $0.785-0.895$ & 0.758 \\
Green Purchasing (GP) & $0.695-0.987$ & 0.612 \\
Eco-design and Packaging (EDP) & $0.568-0.892$ & 0.712 \\
Warehousing and Green Building & $0.695-0.854$ & 0.711 \\
(WGB) & & \\
Environmental Performance (EP) & $0.561-0.758$ & 0.825 \\
Financial Performance (FP) & $0.717-0.895$ & 0.698 \\
Operational Performance (OP) & $0.698-0.784$ & 0.794 \\
All items & & 0.894 \\
\hline
\end{tabular}

\section{Dataanalysis and Hypotheses Testing}

\subsection{Data Analysis Results}

There was been used the descriptive method for this study, and the matrix of relationship between the variables of the study as shown table 2, as shown the value of the means were higher than the median for all dimensions, and partnership building were the highest (4.001), and operational performance was the lowest (3.001), as the correlation matrix showed that there were a high group of positive relationship between the variables of the study, and this confirms the availability of a high degree ofinternal consistency betweenthe variables andexpresses sincerity ofbuildingcontents. 
Table 2. Descriptive statistics and correlation matrix

\begin{tabular}{lllllllll}
\hline Variables & IEM & CWC & GP & EDP & WGB & EP & FP & OP \\
Mean & 3.251 & 4.001 & 3.547 & 3.612 & 3.335 & 3.910 & 3.427 & 3.001 \\
S.D & 0.532 & 0.624 & 0.421 & 0.529 & 0.781 & 0.9201 & 0.804 & 0.621 \\
IEM & 1 & & & & & & & \\
CWC & $.356^{* *}$ & 1 & & & & & & \\
GP & $.458^{* *}$ & $.658^{* *}$ & 1 & & & & & \\
EDP & $.365^{* *}$ & $.614^{* *}$ & $.821^{* *}$ & 1 & & & & \\
WGB & $.412^{* *}$ & $.502^{* *}$ & $.723^{* *}$ & $.736^{* *}$ & 1 & & & \\
EP & $.398^{* *}$ & $.710^{* *}$ & $.621^{* *}$ & $.670^{* *}$ & $.782^{* *}$ & 1 & & \\
FP & $.403^{* *}$ & $.451^{* *}$ & $.389^{* *}$ & $.487^{* *}$ & $.821^{* *}$ & $.509^{* *}$ & 1 & \\
OP & $.311^{* *}$ & $.394^{* *}$ & $.614^{* *}$ & $.502^{* *}$ & $.638^{* *}$ & $.704^{* *}$ & $.754^{* *}$ & 1 \\
\hline
\end{tabular}

$* * \mathrm{P}<0.05$.

The table 3 showed the demographic characteristics for respondents, and most sample were males (89.3\%), and also (30.1\%) were average ages of (41-50) years, and the number of years in working (9-12) years which represented by $(28.5 \%)$, and $(39.8 \%)$ of the sample were from the supervisors and $(14.2 \%)$ of head of department in the firms, and (85\%) of them were from the managers.

Table 3. Respondents' demographic characteristics

\begin{tabular}{|c|c|c|c|}
\hline \multicolumn{4}{|c|}{$\begin{array}{l}\text { Gender: } \\
\text { male } \\
\text { female }\end{array}$} \\
\hline \multicolumn{4}{|c|}{ Age: } \\
\hline- & Less than 25 & $10.3 \%$ & \\
\hline - & $25-30$ & $15.3 \%$ & \\
\hline - & $31-40$ & $23.7 \%$ & \\
\hline - & $41-50$ & $30.1 \%$ & \\
\hline - & $51-60$ & & \\
\hline- & more than 60 & $20.6 \%$ & \\
\hline \multicolumn{4}{|c|}{ No. of years working in the company: } \\
\hline - & 3years and less & $12.3 \%$ & \\
\hline - & $4-8$ & $11.9 \%$ & \\
\hline- & $9-12$ & $28.5 \%$ & \\
\hline- & $13-17$ & $22.3 \%$ & \\
\hline- & 18 and more & $25 \%$ & \\
\hline \multicolumn{4}{|c|}{ Education: } \\
\hline \multicolumn{2}{|c|}{ High School } & $16.6 \%$ & \\
\hline \multicolumn{2}{|c|}{ After H. School } & $25.3 \%$ & \\
\hline \multicolumn{2}{|c|}{ Bachelor } & $58.1 \%$ & \\
\hline \multicolumn{4}{|c|}{ Job Title: } \\
\hline \multicolumn{3}{|c|}{ General Managerial } & $8.5 \%$ \\
\hline \multicolumn{3}{|c|}{ Assistance General Managerial } & $15.2 \%$ \\
\hline \multicolumn{3}{|c|}{ Head of Department } & $14.2 \%$ \\
\hline \multicolumn{3}{|c|}{ Assistance Head of Department } & $22.3 \%$ \\
\hline \multicolumn{3}{|c|}{ Supervisor } & $39.8 \%$ \\
\hline \multicolumn{4}{|c|}{ No. of respondents: (143) } \\
\hline
\end{tabular}

\subsection{Hypothesis Testing}

The study was deal with four hypothesis, for testing the first hypothesis, there was used the simple regression shown in table 4, which indicated that there were positive impact for the practices of green supply chain management (combined) on the dimensions of organizational performance(combined), the value of beta was (55.2\%) with (0.000) significant. while $R^{2}$ was (.658) which means (65.8) of the variables in the organizational performance were because of the practices of green supply chain management. That mean rejected the null hypotheses and accepted the alternative hypotheses :there is an impact of green supply chain management practices(combined);(internal environmental management, collaboration with customers, green purchasing, 
eco-design and packaging, and warehousing and green) on organizational performance(combined)( environment performance, financial performance, and operational performance).

Table 4. Simple regression results: green supply chain management practices on organizational performance

\begin{tabular}{llll}
\hline Variables & Beta & $\mathrm{t}$ & Sig.* \\
\hline $\begin{array}{l}\text { Green supply chain management Practices } \\
\left(\mathrm{R}=.552 ; \mathrm{R}^{2}=.658 ; \mathrm{F}=9.324\right) * \mathrm{p} \leq 0.05\end{array}$ & .552 & 2.073 & $.000^{*}$ \\
\hline
\end{tabular}

While the other three hypotheses shown in table 5, that the second hypothesis indicated that (IEM, WGB, GP, CWC) were the highest effect in organizational performance related to the environment, while (EDP) had no effect in the environment. The third hypothesis showed that (IEM, CWC, GB, WGB, and EDP) got affect on the organizational performance that related to the financial aspects, while the forth hypothesis that (IEM, GP) were only the factors that affect on the organizational performance that related to the operational aspects.

Table 5. Results of stepwise regressionanalyses for the sub hypotheses

\begin{tabular}{llll}
\hline \multirow{2}{*}{ Independent Variables } & \multicolumn{3}{l}{ Dependent Variables } \\
& EP & FP & OP \\
& Beta & Beta & Beta \\
& $(\mathrm{sig})$ & $(\mathrm{sig})$ & $($ sig) \\
IEM & .293 & .325 & .445 \\
& $\left(.000^{*}\right)$ & $\left(.000^{*}\right)$ & $\left(.000^{*}\right)$ \\
CWC & .335 & .425 & .067 \\
& $\left(.002^{*}\right)$ & $\left(.002^{*}\right)$ & $(.098)$ \\
GP & .235 & .356 & .389 \\
& $\left(.001^{*}\right)$ & $\left(.000^{*}\right)$ & $\left(.000^{*}\right)$ \\
EDP & .102 & .225 & .015 \\
& $(.064)$ & $\left(.004^{*}\right)$ & .156 \\
WGB & .243 & .286 & .098 \\
& $(.007 *)$ & $\left(.000^{*}\right)$ & $(.136)$ \\
& $\mathrm{R}=.482 ;$ & $\mathrm{R}=.336 ;$ & $\mathbf{R}=.197 ; \mathbf{R}^{2}=. \mathbf{2 8 9}$ \\
& $\mathrm{R}^{2}=.382$ & $\mathrm{R}^{2}=.293$ & \\
\hline
\end{tabular}

\section{Result and Conclusion}

The research tries to figure out the impact of green supply chain management practices on organizational performance. The researcher built the model and hypothesis based on the dimensions of green supply chain management practices. The researcher collected the data based on the secondary and primary data which built with surveys. The researchers choose (6) firms specialized in industrial food sector and which the firms that applied the concept of green manufacturing. Also the results showed that green supply chain management practices and its elements on organizational performance, (positive impact for the practices of green supply chain management on the organizational performance).

\section{Implications and Recommendations}

\subsection{Academic Implications}

For academic implications: In this research the researchers study a new factors include environmental performance and financial performance beside the other factor (Operational Performance), in addition to make a new model \& a new study for future research.

\subsection{Managerial Implications}

This study will play important role for managers and firms, also this study is contributing in increasing the sales through understanding the green supply chain management and got the highest benefits from it.

\subsection{Recommendations}

The researchers suggested some recommendations, which are Continuing coordination between the different administrative levels to implement the green supply chain, in order to achieving the highest level of quality in this area, trying tofind the most friendly for environmentalraw materials which its used in the food industry. And 
continuingin Safety environmental design and packaging, create an annual training plan according to the workers training needs related to the green supply chain,increased the budget allocated for scientific research in the field of green supply chain, and finally activated the governmental rules and regulations to be more careful about the safety of the environment.

\section{Acknowledgement}

The Authors are Grateful to The Applied Science University, Amman, Jordan for the full financial support granted to this research project (Grant No.BI $\backslash 99$ ).

\section{References}

Alvarez Gil, M. J., Jimenez, J. B., \& Lorente, J. C. (2001). An analysis of Environmental Management, organizational context and performance of Spanish hotels. Omega journal, 29(6), 457-471. http://dx.doi.org/10.1016/S0305-0483(01)00033-0

Bjorklund, M. et al. (2012). Performance Measurement in the Greening of Supply Chains. International Journal of supply chain Management, 17(1), 29-39. http://dx.doi.org/10.1108/13598541211212186

Carter, C. R., \& Carter, J. R. (1998). Inter-organizational determinants of Environmental Purchasing: initial evidence from the consumer products industry. Decision Sciences Journal, 29(3), 88-98. http://dx.doi.org/10.1111/j.1540-5915.1998.tb01358.x

Carter, C. R., Ellram, L. M., \& Kathryn, L. M. (1998). Environmental Purchasing: benchmarking our German counterparts. International Journal of Purchasing \& Materials Management, 34(4), 28-38. http://dx.doi.org/10.1111/j.1745-493X.1998.tb00299.x

Carter, C. R., Kale, R., \& Grimn, C. M. (2000). Environmental purchasing and Firm performance: an empirical $\begin{array}{llllll}\text { investigation. Transportation } & \text { Research } & \text { Part } & \text { 219-228. }\end{array}$ http://dx.doi.org/10.1016/S1366-5545(99)00034-4

Chandra, C., \& Tumanyan, A. (2005). Supply Chain System Taxonomy: A Framework and Methodology. Human System Management, 24(4), 245-258.

Faruk, A. C., Lamming, R. C., Cousins, P. D., \& Bowen, F. E. (2002). Analyzing, mapping and managing environmental impacts along the supply chain. Journal of Industrial Ecology, 5(2), 13-36. http://dx.doi.org/10.1162/10881980152830114

Green, Jr. K. W., Zelbst, P. J., Meacham, J., \& Bhadauria, V. S. (2012). Green supply chain management practices: impact on performance, necessary and good business. Supply Chain Management: An International Journal, 17(3), 290-305. http://dx.doi.org/10.1108/13598541211227126

Gupta, M. (1995). Environmental management and its impact on the operations function. International Journal of Operations \& Production Management, 15(8). http://dx.doi.org/10.1108/01443579510094071

Hervani, A. A., Helm, M. M., \& Sarkis, J. (2005). Performance Measurement for green supply chain management. Benchmarking: An International Journal, 12(4), 330-353. http://dx.doi.org/10.1108/14635770510609015

Holt, D., \& Ghobadain, A. (2009). An empirical study of green supply Chain management practices among U.K. manufactures. Journal of Manufacturing Technology Management, 20(7), 933-956. http://dx.doi.org/10.1108/17410380910984212

Melnyk, S. A., Sroufe, R. P., \& Calatone, R. (2002). Assessing the impact of Environmental management systems on corporate and Environmental performance. Journal of Operations Management, 21(2), 329-351.

Min, H., \& Galle, W. P. (1997). Green purchasing strategies: trends and implications. International Journal of $\begin{array}{llll}\text { Purchasing and } & \text { Materials }\end{array}$ http://dx.doi.org/10.1111/j.1745-493X.1997.tb00026.x

Molina, J. F., \& Lopez, M. D. (2009). Green Management and Financial Performance: literature Review. Journal of Management Decision, 47(7), 1080-1100. http://dx.doi.org/10.1108/00251740910978313

Perotti, S. et al. (2012). Green supply chain practices and company performance: The case of 3pls in Italy. International Journal of Physical, Distribution and Logistics Management, 42(7), 640-672. http://dx.doi.org/10.1108/09600031211258138

Sarkis, J. (2003). A strategic decision making framework for green supply Chain management. Journal of Cleaner Production, 11(4), 397-409. http://dx.doi.org/10.1016/S0959-6526(02)00062-8 
Sarkis, J. (2011). A boundaries and flows perspective of green supply chain management. Supply Chain Management: An International Journal, 17(2), 202-216. http://dx.doi.org/10.1108/13598541211212924

Shi, V. G., Lenny Koh, S. C., Baldwin, J., \& Cucchiella, F. (2012). Natural resource based green supply chain management. Supply Chain Management: An International Journal, 17(1), 54-67. http://dx.doi.org/10.1108/13598541211212203

Shultz, C. J., \& Holbrook, M. B. (1999). Marketing and Tragedy of The Commons: A synthesis, Commentary and Analysis for Action. Journal of Public Policy and Marketing, 18(2), 218-229.

Stephanie, S., Haden, P., Oyler, J. D., \& Humphreys, J. H. (2009). Historical, practical, and theoretical perspectives on green management, An exploratory analysis. Management Decision, 47(7), 1041-1055. http://dx.doi.org/10.1108/00251740910978287

Theyel, G. (2001). Customer and supplier relations for environmental performance. Greener Management International, 35, 61-69. http://dx.doi.org/10.9774/GLEAF.3062.2001.au.00007

Vachon, S., \& Kalsson, R. (2007). Supply Chain Management and Environmental Technologies-The Role of Integration. International Journal of Production Research, 45(2), 401-423. http://dx.doi.org/10.1080/00207540600597781

Zhu, Q., \& Sarkis, J. (2004). Relationship between Organizational practices and Performance among early adapters of green supply chain Management practices in Chinese manufacturing Enterprises. Industrial Management and Data Systems, 7(2), 313-320.

Zhu, Q., \& Sarkis, J. (2007). Green supply chain management: pressures, practices and performance within the Chinese automobile industry. Journal of Cleaner Production, 15(2), 1041-1052.

\section{Copyrights}

Copyright for this article is retained by the author(s), with first publication rights granted to the journal.

This is an open-access article distributed under the terms and conditions of the Creative Commons Attribution license (http://creativecommons.org/licenses/by/3.0/). 